\title{
ПОБУДОВА Й АНАЛІЗ МОДЕЛІ ПРИЙНЯТТЯ РІШЕНЬ ПРИ ОЦІНЦІ НАСЛІДКІВ ВАКЦИНАЦІЇ ПРОТИРОТАВІРУСНОЮ ВАКЦИНОЮ В УКРАЇНІ
}

\author{
С. О. Соловйов, І. В. Дзюблик \\ Національна медична академія післядипломної освіти імені П. Л. Шупика
}

\begin{abstract}
Представлені результати розрахунково-теоретичних досліджень, пов'язаних з оцінкою показників ефективності вакцинопроффілактики протиротавірусною вакциною в Україні серед дітей віком до п'яти років. Показники цього впливу отримані реалізацією комп'ютерної моделі дерева прийняття рішень на основі Марківських процесів. В рамках стратегій вакцинації і без вакцинації отримані прогнозні показники захворюваності, кількості госпіталізацій, смертності при ротавірусній інфекції та інші показники. Показано, що вакцинопрофрілактика протиротавірусною вакциною матиме суттєве медичне значення в Україні.
\end{abstract}

Ключові слова: ротавірусна інфекція, вакцинопрофілактика, дерево прийняття рішень, Марківський процес.

\section{ПОСТРОЕНИЕ И АНАЛИЗ МОДЕЛИ ПРИНЯТИЯ РЕШЕНИЙ ПРИ ОЦЕНКЕ ПОСЛЕДСТВИЙ ВАКЦИНАЦИИ ПРОТИВОРОТАВИРУСНОЙ ВАКЦИНОЙ В УКРАИНЕ}

\author{
Национальная медицинская академия последипломного образования им П. Л. Шупика
}

Представлены результаты расчетно-теоретических исследований, связанных с оценкой показателей эффективности вакцинопрофилактики противоротавирусной вакциной в Украине среди детей в возрасте до пяти лет. Показатели этого воздействия получены реализацией компьютерной модели дерева принятия решений на основе Марковских процессов. В рамках стратегий вакцинации и без вакцинации получены прогнозные показатели заболеваемости, количества госпитализаций, смертности при ротавирусной инфекции и другие показатели. Показано, что вакцинопрофилактика противоротавирусной вакциной будет иметь существенное медицинское значение в Украине.

Ключевые слова: ротавирусная инфекция, вакцинопрофилактика, дерево принятия решений, Марковский процесс.

\section{CONSTRUCTION AND ANALYSIS OF DECISION-MAKING MODEL IN ASSESSING THE IMPACT OF VACCINATION WITH ROTAVIRUS VACCINE IN UKRAINE}

\author{
National Medical Academy of Post-Graduate Education named after P. L. Shupyk
}

The results of computational and theoretical studies related to assessing of efficiency indicators of immunization with rotavirus vaccine in Ukraine among children under five years are presented. The Indicators of the impact were received with computer implementation of decision tree model based on Markov processes. Under strategies of vaccination and no vaccination projected levels of morbidity, number of hospital admissions, mortality of rotavirus infection and other factors were received. It was shown that the vaccination with rotavirus vaccine will have significant medical significance in Ukraine.

Key words: rotavirus, vaccine, vaccination, decision tree, Markov process.

Вступ. Гострі кишкові інфекції (ГКІ) є однією 3 найбільш значущих проблем охорони здоров'я в усіх країнах світу. Спектр збудників, що викликають ГКІ, різноманітний і включає патогенні та умовнопатогенні бактерії, найпростіші, а також віруси. Серед них саме ротавірусній інфекції (РВI) належить провідна роль в структурі вірусних діарейних захворювань у новонароджених і дітей віком до 5 років $[1,2]$.

Статистичний облік захворюваності на ротавірусні гастроентерити в Україні введений лише на початку 90-х років ХХ століття, при цьому показники захворюваності на ротавірусну інфекцією в окремі роки

(C) С. О. Соловйов, І. В. Дзюблик 
коливалися від 0,94 до 3,18 на 100 тисяч населення. Великі спалахи РВІ були зареєстровані в м. Одеса та Одеській області у 2000-2001 роках з залученням в епідемічний процес понад 1300 осіб та у м. Києві в 2003 році, коли захворіло понад 500 дітей. Описані випадки нозокоміальної ротавірусної інфекції в родопомічних закладах, спеціалізованих неонатологічних відділеннях, лікувально-профілактичних установах України [3, 4]. В той же час такі дослідження є точковими і не в повному обсязі відображають картину медичної проблеми РВI в Україні.

Вакцинація, як найбільш дієвий засіб специфічної профілактики ротавірусної інфекції, визнана у всьому світі. Жива атенуйована протиротавірусна вакцина Ротарікс $^{\mathrm{TM}}$ на основі штаму ротавірусів RIX4414 була запатентована у 35 країнах світу, в тому числі в Свропейському Союзі [5]. У 2009 році Ротарікстм була зареєстрована в Україні (Р.С. МО3 України № 735/ 09-300200000 від 10 червня 2009 р.), а вакцинація проти PBI введена в Національний календар щеплень (Розділ "Рекомендовані щеплення") [6]. I хоча клінічна ефективність вакцини Ротарікс ${ }^{\mathrm{TM}}$ підтверджена мультицентровими дослідженнями серед дітей у ряді країн Європи і в Латинській Америці (близько 90000 дітей першого року життя) [7-9], потенційний ефект вакцинопрофілактики серед дітей України досить складно прогнозувати.

Новим підходом до прогнозування медичного значення вакцинації протиротавірусною вакциною є комп'ютерне моделювання медичної проблеми РВІ з використанням Марківських процесів на основі клініколабораторних спостережень та молекулярногенетичного моніторингу ізолятів ротавірусів, що і послужило метою нашого дослідження.

Методологічні підходи до моделювання та опис моделі. Аналіз ефективності вакцинопрофілактики PBI проводився 3 використанням методу моделювання за допомогою програми TreeAge Pro 2009 (Williamstown, MA). Для дитячої вікової групи до п'яти років була розроблена модель прийняття рішення 3 використанням в якості аналога моделі, запропонованої J. Rose [10]. Створення моделі було засновано на основі описання перебігу PBI у дітей цієї вікової категорії на фоні проведення вакцинопрофілактики вакциною Ротарікс ${ }^{\mathrm{TM}}$ у рекомендованому віці 2 та 4 місяців [11] і без неї залежно від можливих варіантів перебігу хвороби. Результатом цього стало створення «дерева рішень» (Decision trees) - схеми або алгоритму всіх прогнозованих варіантів перебігу захворювання (рис. 1). Побудова «дерева рішень» була заснована на визначенні альтернативних підходів до хворої дитини, описанні успішних і неуспішних результатів, оцінки ступеня ймовірності їх настання в процентах та проаналізована на основі Марківських процесів методом Монте-Карло - симулюванням великої кількості випадкових станів окремої дитини.

Використання Марківських процесів в медицині було запропоновано Beck та Pauker в 1983 році [12, 13], і сьогодні такий підхід, за даними електронної бази медичних знань PubMed, є досить потужним інструментом при вирішенні медичних проблем [14]. Марківські моделі звичайно представляють у вигляді дерева Марківських циклів, в якому кожен стан відображається у вигляді відгалуження від Марківського вузла. Марківський процес визначається розподілом ймовірностей між початковими станами i ймовірностями переходів, які припустимі для окремих груп хворих (відсоток людей на кожній стадії захворювання, які видужують, переносять ускладнення й/або гинуть). Припинення Марківського процесу можливо, якщо хворі, яких обстежили, після проходження достатньої кількості циклів переходять у замкнутий стан (тобто адсорбуються ним), вийти 3 якого вони не можуть. Для медицини адсорбуючим станом є смерть.

Нехай є система $\mathrm{S}$, а в нашому випадку - окрема дитина, що може перебувати в станах, пов'язаних 3 PBI: $\mathrm{S}_{1}, S_{2}, S_{3}, \ldots, S_{n}$ причому зміни стану системи можливі тільки в моменти: $t_{1}, t_{2}, \ldots, t_{k}, \ldots$, які відповідають одному місяцю життя. Будемо називати ці моменти «кроками» або «етапами» процесу і розглядати випадковий процес, що відбувається в системі $\mathrm{S}$, як функцію цілочисельного аргументу: 1,2 , $\ldots, k, \ldots$ (номер кроку).

Випадковий процес, що відбувається в системі, полягає в тому, що в послідовні моменти часу $t_{1}, t_{2}$, $\ldots, t_{k}, \ldots$ система $S$ виявляється в тих чи інших станах, ведучи себе, наприклад, певним чином (в загальному випадку система може не тільки змінювати стан, а й зберігати попередній).

Домовимося позначати $S_{i}^{k,}$ подію, при якій після $\kappa$ кроків система перебуває в стані $\mathrm{S}_{\mathrm{i}}$. При будь-якому $\kappa$ події $S_{1}^{(k)}, S_{2}^{(k)}, \ldots, S_{i}^{(k)}, \ldots, S_{n}^{(k)}$ утворюють повну групу і $є$ несумісними. Процес, що відбувається в системі, можна представити як послідовність (ланцюг) подій, наприклад: $S_{1}^{(0)}, S_{2}^{(1)}, S_{1}^{(2)}, S_{4}^{(3)}, \ldots$ Така випадкова послідовність подій називається Марківським ланцюгом, якщо для кожного кроку ймовірність переходу з будь-якого стану $\mathrm{S}_{\mathrm{i}}$ у будь-який стан $\mathrm{S}_{\mathrm{j}}$ не залежить від того, коли і як система прийшла в стан $\mathrm{S}_{\mathrm{i}}$

Марківський ланцюг можна описати за допомогою ймовірностей станів. Нехай у будь-який момент часу 


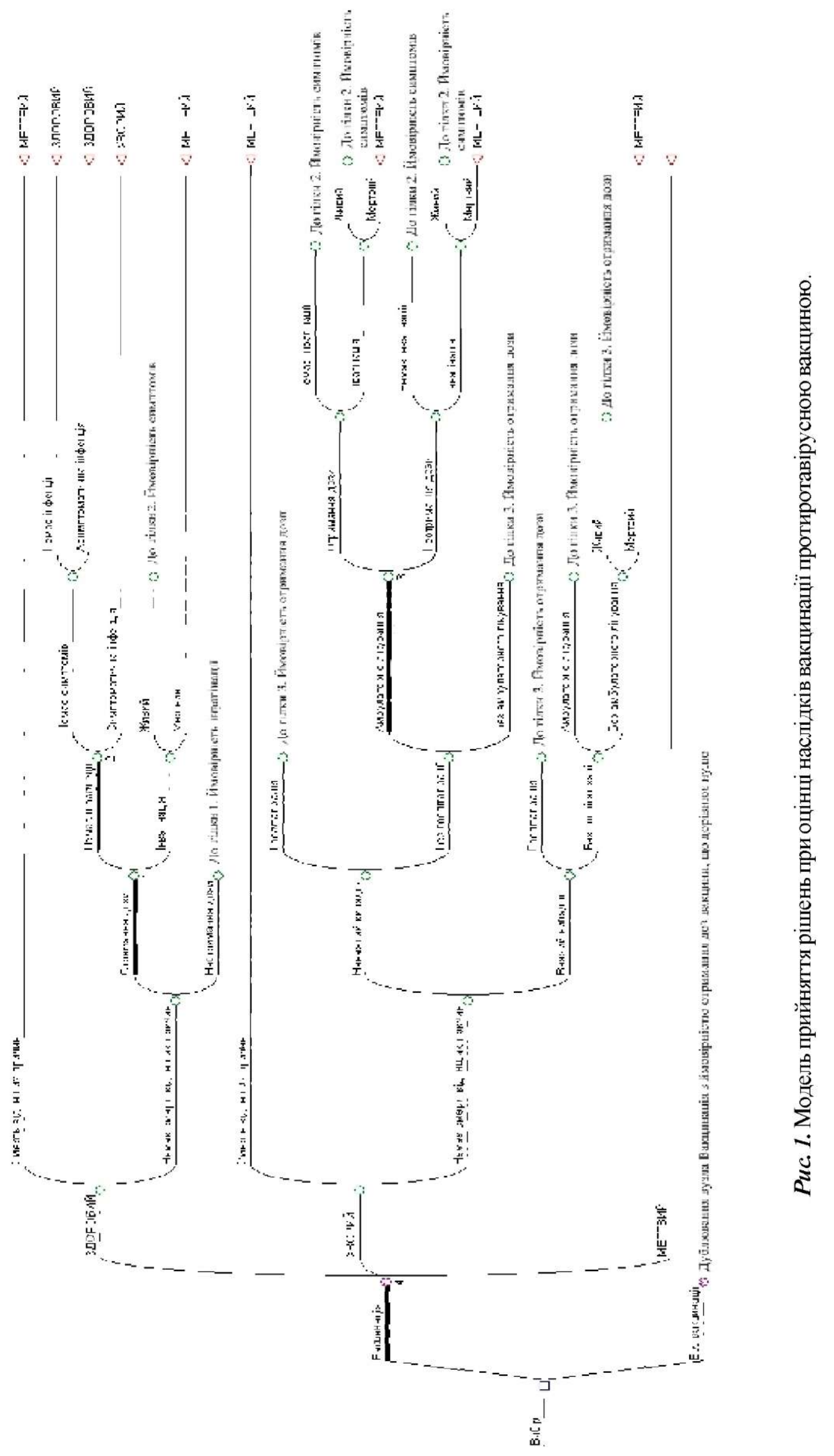


(після будь-якого $k$-го кроку) система $\mathrm{S}$ може бути в одному із станів: $S_{1}, S_{2}, \ldots, S_{n}$, тобто здійсниться одна 3 повної групи несумісних подій: $S_{1}^{(k)}, S_{2}^{(k)}, \ldots$, $S_{i}^{(k)}, \ldots, S_{n}^{(k)}$. Позначимо ймовірності цих подій для к-го кроку через: $p_{1}(k)=p\left(S_{1}^{(k)}\right), p_{2}(k)=p\left(S_{2}^{(k)}\right), \ldots$, $p_{i}(k)=p\left(S_{i}^{(k)}\right), \ldots, p_{n}(k)=p\left(S_{n}^{(k)}\right)$

Для кожного номера кроку $к$

$p_{1}(k)+p_{2}(k)+\ldots+p_{n}(k)=1$

оскільки це - ймовірності несумісних подій, що утворюють повну групу. Ймовірності $p_{1}(k), p_{2}(k), \ldots$,

будемо називати ймовірностями стану. В сукупності вони утворюють вектор:

$$
p^{(k)}=\left(p_{1}(k), p_{2}(k), \ldots, p_{n}(k)\right)
$$

Випадковий процес (Марківський ланцюг) можна уявити собі так, ніби точка, яка зображає систему $\mathrm{S}$, випадковим чином переміщується (блукає) по графу станів, а в нашому випадку по дереву рішень, перескакуючи зі стану в стан в моменти $t_{1}, t_{2}, \ldots, t_{k}, \ldots$, а іноді (в загальному випадку) затримуючись на якесь число кроків в одному і тому ж стані.

Для будь-якого кроку (моменту часу $t_{1}, t_{2}, \ldots, t_{k}, \ldots$ або номера $1,2, \ldots, k, \ldots)$ існують деякі ймовірності переходу системи з будь-якого стану в будь-який інший (деякі з них дорівнюють нулю, якщо безпосередній перехід за один крок неможливий), а також ймовірність затримки системи в даному стані. Будемо називати ці ймовірності перехідними ймовірностями Марківського ланцюга.

Розглянемо в нашому випадку однорідний Марківський ланцюг. Позначимо через $P_{i j}$ ймовірність переходу за один крок зі стану $S_{i}$ в стан $\mathrm{S}_{\mathrm{j}} P_{i j}$ буде ймовірністю затримки системи в стані $S_{i}$. Запишемо дані ймовірності у формі квадратної матриці:

$$
P=P_{i j}=\left(\begin{array}{ccc}
P_{11} & \ldots & P_{1 n} \\
\vdots & \ddots & \vdots \\
P_{n 1} & \cdots & P_{n n}
\end{array}\right)
$$

Деякі з ймовірностей переходу $P_{i j}$ можуть бути рівні нулю, що означає неможливість переходу системи 3 $i$-того стану в $j$-тий стан за один крок. По головній діагоналі матриці перехідних ймовірностей стоять $P_{i j}$ ймовірності того, що система не вийде зі стану $S_{i}$ а залишиться в ньому.

Сума членів, що стоять у кожному рядку матриці (3), повинна дорівнювати одиниці, оскільки в якому б стані система не була перед k-тим кроком, події $S_{1}^{(k)}$,
$S_{2}^{(k)}, \ldots, S_{i}^{(k)}, \ldots, S_{n}^{(k)}$ несумісні і утворюють повну групу.

Маючи в розпорядженні матрицю перехідних ймовірностей і знаючи початковий стан системи, можна знайти ймовірності станів $p_{1}(k), p_{2}(k), \ldots, p_{n}(k)$ після будь-якого к-того кроку.

За формулою повної ймовірності отримаємо:

$p_{i}(k)=\sum_{j=1}^{n} p_{j}(k-1) P_{j i},(i=1, \ldots, n)$

або в матричній формі

$p_{i}^{(k)}=P^{T} \times p^{(k-1)}$

Отже, ймовірності станів $p_{i}(k)$ після $k$-того кроку визначаються рекурентною формулою (4) через імовірності станів після ( $k$-I)-того кроку, ті, в свою чергу, - через імовірності станів після $(k-2)$-го кроку, і т. д.

Створена модель передбачає, що кожна дитина народжується в здоровому стані і надалі може перебувати в здоровому, симптоматичному, або мертвому стані протягом кожного з 60 місячних циклів, що відповідає віку дитини до п'яти років (рис. 1). Дитина може отримувати кожну дозу протиротавірусної вакцини тільки на другий і четвертий місяць (цикл) життя. В кінці кожного циклу ризик захворювання ротавірусною інфекцією визначається кількістю отриманих доз вакцини і кількістю попередніх ротавірусних інфекцій. В інфікованому стані можуть розвиватися симптоми і в цьому випадку дитина починає наступний цикл також в симптоматичному стані. В такому стані ротавірусний гастроентерит може бути в неважкій (<11 балів за шкалою Vesikari) або важкій (>11 балів за шкалою Vesikari) формах. Серйозність симптомів впливає на ймовірність того, який вид лікування обере хворий - стаціонарне, амбулаторне або лікування вдома. В кінці циклу, проведеного в хворому стані, людина що одужала, може перейти в здоровий стан або захворіти новою симптоматичною ротавірусною інфекцією та розпочати новий цикл в стані хвороби. Особи з тяжкими формами захворювання, які не отримують належного лікування, мають більш високу ймовірність смерті. Крім того, протягом кожного циклу існує залежна від віку ймовірність смерті від причин, не пов'язаних з ротавірусною інфекцією (за таблицями дожиття). Знак (М) представляє собою Марківський вузол, а гілки, що виходять з Марківських вузлів, представляють можливі стани. Знак О вказує на ймовірнісний вузол, а гілки, що виходять 3 нього, представляють можливі результати ймовірнісного процесу. Знаком позначається термінальний вузол зі станом, у якому по- 
винен початись наступний цикл. "Отримання дози " означає, що особи отримують дозу вакцини, або не отримують в разі "Не отримання дози".

Після завершення моделювання на одній особі, на іншій виконується нове моделювання, яке починається в здоровому стані. На основі моделювання методом Монте-Карло великої кількості (порядку 104) подібних осіб з окремою траєкторією кожної особи крізь Марківський ланцюг, що визначений законами ймовірності, відповідно може бути обрахована усереднена або очікувана ймовірність того чи іншого стану. В нашій моделі методом Монте-Карло ми симулювали випадкові стани 100000 осіб, що є достатньою вибіркою для вказаного методу.

Параметри, використані при моделюванні. Показники захворюваності на ротавірусну інфекцію аналогічні в усьому світі [15]. Тому для моделі були використані параметри, які відносяться до ризику інфекції, отримані з результатів дослідження ротавірусної інфекції в когорті 200 мексиканських немовлят віком від одного до двадцяти чотирьох місяців [16]. Базуючись на отриманій кумулятивній ймовірності $n$-тої інфекції, на інтервалі 6, 12 та 24 місяці, ми розрахували ризик захворюваності протягом місяця та перевели його в ймовірність інфікування згідно з віком дитини та кількістю попередніх інфекцій. Ризик захворюваності для 12- та 24-місячних інтервалів був покладений в основу ймовірностей переходу в Марківській моделі для $n$-тої інфекції після 24-го циклу. Дані з дослідження цієї когорти дітей були використані також як основа для отримання ймовірностей того, що інфіковані діти не будуть мати симптоми, матимуть нетяжкі симптоми або матимуть тяжкі симптоми при першій, другій та третій інфекціях. Тяжкість або відсутність симптомів не впливає на рівень природного захисту при паралельній ко-інфекції [17]. Крім того, на кожному циклі всі особи стикались з залежною від віку ймовірністю смерті від причин, не пов'язаних з PBI, основаною на таблицях дожиття для України [18]. Ці та інші розраховані параметри наведені в табл. 1.

Таблиця 1. Параметри, використані при моделюванні

\begin{tabular}{|c|c|c|}
\hline Параметри & Значення & Джерело/примітки \\
\hline \multicolumn{3}{|c|}{ Кумулятивна частота інфекцій в 6,12 і 24 місяці*: } \\
\hline Перша інфекція & 0,$34 ; 0,67 ; 0,96 * *$ & \multirow{5}{*}[16]{} \\
\hline Друга інфекція & 0,$04 ; 0,30 ; 0,69$ & \\
\hline Третя інфекція & 0,$00 ; 0,07 ; 0,42$ & \\
\hline $\begin{array}{l}\text { Ймовірність того, що 1, } 2 \text { і 3-я інфекції будуть, відповідно, } \\
\text { викликати симптоми }\end{array}$ & 0,$47 ; 0,32 ; 0,25$ & \\
\hline $\begin{array}{l}\text { Ймовірність, що наявні симптоми будуть тяжкими }(1,2, \\
\text { 3-я інфекції)*** }\end{array}$ & 0,$28 ; 0,19 ; 0,00$ & \\
\hline Ймовірність госпіталізації з РВІ у віці до п'яти років & 0,0181 & [19-21] \\
\hline $\begin{array}{l}\text { Ймовірність амбулаторного відвідування з приводу РВІ у } \\
\text { віці до п' яти років }\end{array}$ & 0,145 & [15] \\
\hline Ймовірність смерті від тяжкої ротавірусної інфекції & 0,00005 & [19] \\
\hline $\begin{array}{l}\text { Ймовірність смерті від тяжкої ротавірусної інфекції без } \\
\text { надання медичної допомоги }\end{array}$ & 0,0002 & на основі калібрування моделі \\
\hline Покриття першою дозою (вік 2 місяці) & 0,73 & $\begin{array}{l}\text { На основі покриття вакциною } \\
\text { АКДП -1 в Україні [18] }\end{array}$ \\
\hline Покриття другою дозою (вік 4 місяці) & 0,90 & $\begin{array}{l}\text { На основі покриття вакциною } \\
\text { АКДП -3 в Україні [18] }\end{array}$ \\
\hline \multicolumn{3}{|c|}{ Ефективність вакцини проти тяжкого гастроентериту, викликаного штамами ротавірусів із: } \\
\hline $\begin{array}{l}\text { G та P генотипами, гомологічними вакцинному штаму } \\
\text { RIX4414 }\end{array}$ & 0,908 & \multirow{3}{*}{ [7] } \\
\hline $\begin{array}{l}\text { G або P генотипами, гомологічними вакцинному штаму } \\
\text { RIX4414 }\end{array}$ & 0,869 & \\
\hline $\begin{array}{l}\text { G та P генотипами, не гомологічними вакцинному штаму } \\
\text { RIX4414 }\end{array}$ & 0,714 & \\
\hline $\begin{array}{l}\text { Відношення значення ефективності проти будь-якої } \\
\text { симптоматичної ротавірусної інфекції до значення } \\
\text { ефективності проти тяжкої інфекції }\end{array}$ & 0,873 & [9] \\
\hline
\end{tabular}


Продовження табл. 1

\begin{tabular}{|c|c|c|}
\hline Параметри & Значення & Джерело/примітки \\
\hline $\begin{array}{l}\text { Відношення значення ефективності проти будь-якої } \\
\text { асимптоматичної ротавірусної інфекції до значення } \\
\text { ефективності проти тяжкої інфекції }\end{array}$ & 0,437 & {$[16]$} \\
\hline Повна ефективність однієї дози & 0,625 & {$[22]$} \\
\hline $\begin{array}{l}\text { Прогнозна щорічна швидкість зменшення ефективності } \\
\text { вакцини }\end{array}$ & 0,049 & $\begin{array}{l}\text { на основі спостережного } \\
\text { зниження ефективності } \\
\text { вакцини між першим та } \\
\text { другим сезоном у Латинській } \\
\text { Америці [23] }\end{array}$ \\
\hline \multicolumn{3}{|c|}{ Циркуляція штамів ротавірусів 3: } \\
\hline \multicolumn{2}{|c|}{ G та Р генотипами, гомологічними вакцинному штаму 0,33} & \multirow{3}{*}{$\begin{array}{l}\text { За власними даними } \\
\text { молекулярно-генетичного } \\
\text { моніторингу циркуляції } \\
\text { ротавірусів в Україні [24-26] }\end{array}$} \\
\hline G або Р генотипами, гомологічними вакци & штауу $_{51}$ & \\
\hline \multicolumn{2}{|c|}{ G та Р генотипами, не гомологічними вакцинному штаму 6} & \\
\hline
\end{tabular}

* Ризик інфекції $\mathrm{r}=\ln (1-\mathrm{p}) / \mathrm{t}_{1}$ де $\mathrm{t}_{1}$ - довжина інтервалу (наприклад, 6 місяців між 6-тим і 12-тим місяцями життя) і р ймовірність п-тої інфекції до кінця інтервалу при ризику п-тої інфекції на початку інтервалу, ймовірність переходу розраховується як $\mathrm{p}=1-\mathrm{e}^{-1 / 2}$ де $\mathrm{t}_{2}$ - тривалість циклу (один місяць для даної моделі).

* *На підставі спостережень, що інфекції, викликані ротавірусами в перші кілька місяців життя, є нечастим явищем, було покладено, що ймовірність інфікування дитини віком до 2 місяців нульова.

***Тяжкі інфекції відповідають - 11 балів за шкалою Vesikari.

У попередньому дослідженні нами було оцінено генотип-специфічну ефективність вакцини Ротарікс ${ }^{\mathrm{TM}}$ на основі даних молекулярно-генетичного моніторингу циркуляції різних генотипів ротавірусів на території України [24-26]. Було показано, що за умови використання вакцини на території України, кількість тяжких випадків ротавірусної інфекції серед дітей раннього віку буде зменшена на 80,4 \%. Цей результат був покладений в основу прогностичної моделі ефективності вакцинопрофілактики вакциною Ротарікс ${ }^{\mathrm{TM}}$ в Україні.

Результати моделювання. В результаті моделювання було отримано прогнозоване число клінічних подій та використання медичних послуг серед дітей віком до п'яти років та до одного року в рамках обох стратегій при охопленні вакциною на рівні охоплення вакцинами АКДП-1 та АКДП-3 в Україні. Прогнозне охоплення вакциною склало близько 140 тис. доз на 100 тис. дітей. При проведенні вакцинації спостерігатиметься значний позитивний ефект. Так, серед дітей віком до п'яти років спостерігатиметься зниження кількості госпіталізацій, амбулаторних відвідувань та інфекцій з тяжким перебігом хвороби, смертності від РВI (рис. 2). Водночас показано прогнозоване можливе
Puc. 2. Прогнозні клінічні прояви і використання медичних послуг, пов'язаних 3 ротавірусною інфекцією серед $10^{5}$ умовних дітей віком до п'яти років в рамках стратегії без вакцинації та вакцинації вакциною Ротарікс ${ }^{\mathrm{TM}}$ в Україні.

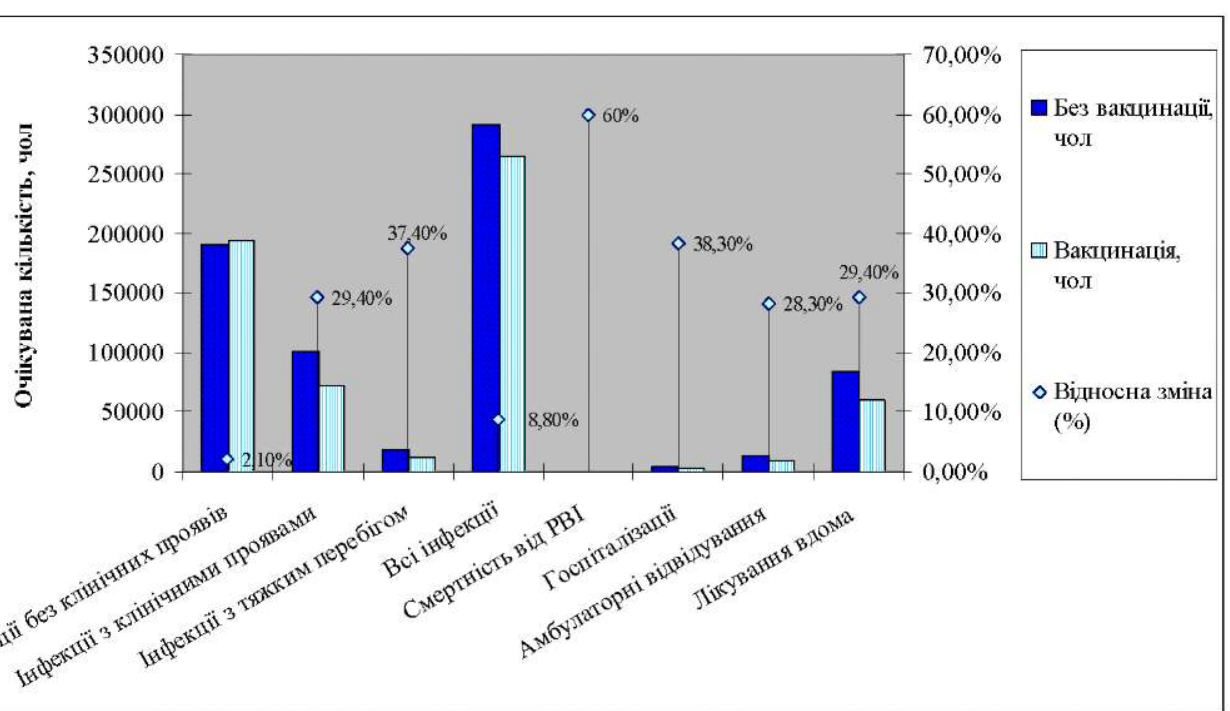


збільшення кількості асимптоматичних інфекцій при проведенні вакцинопрофілактики.

Більш значущим буде ефект вакцинопрофілактики серед немовлят до одного року. Серед цієї вікової групи спостерігатиметься значне зниження госпіталізацій, інфекцій з тяжким перебігом хвороби, смертності від РВІ (рис. 3).

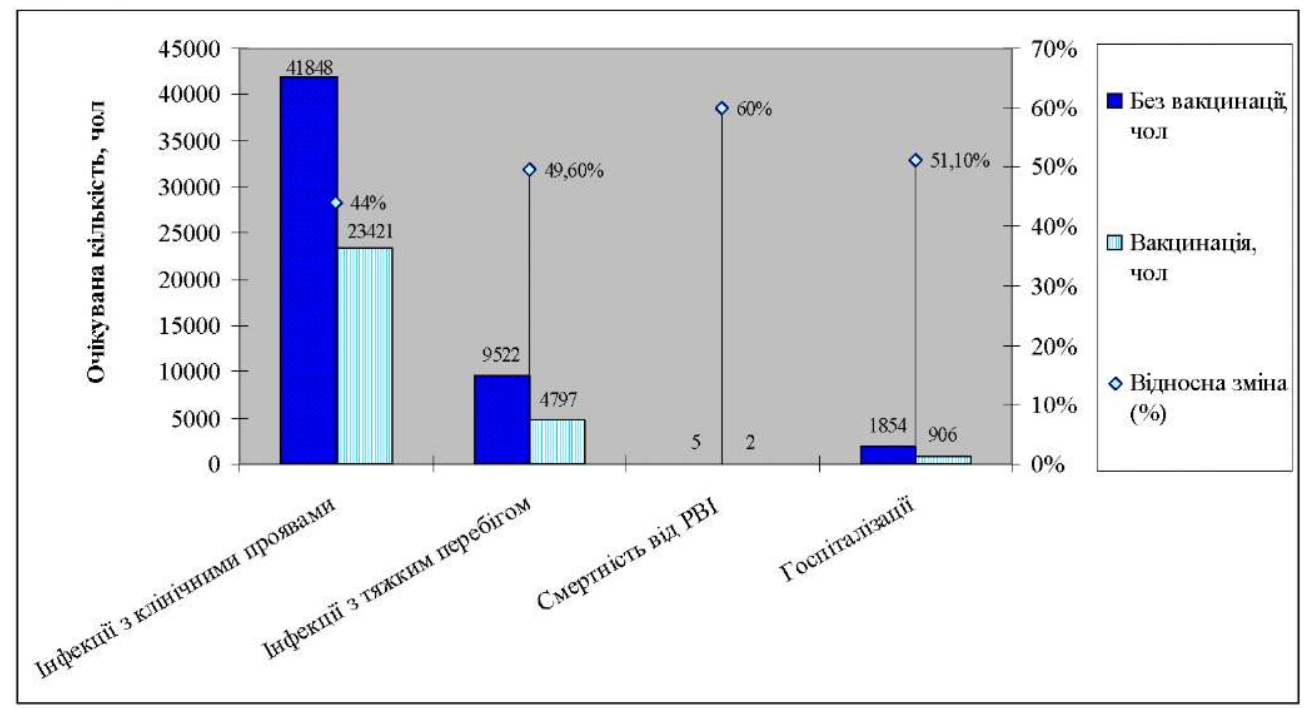

Рис. 3. Прогнозні клінічні прояви і використання медичних послуг, пов'язаних 3 ротавірусною інфекцією серед $10^{5}$ умовних дітей віком до одного року в рамках стратегії без вакцинації та вакцинації вакциною Ротарікстм в Україні.

Висновки. На основі принципово нового підходу математичного моделювання була створена модель прийняття рішень при оцінці наслідків вакцинації протиротавірусною вакциною в Україні та проведена їі комп'ютерна реалізація. Вперше було доведено розрахунками, що ротавірусна інфекція є значною медичною проблемою в Україні. Аналіз моделі показав, що при впровадженні вакцинопрофілактики РВI ефект буде значним як серед дітей до п'яти років,

\section{Література}

1. Rotavirus and severe childhood diarrhea/ U. D. Parashar, C. J. Gibson, J. S. Bresse, R. I. Glass//Emerg. Infect. Dis. 2006. - № 12. - P. 304-306.

2. Burden of rotavirus disease in European Union countries/ M. Soriano-Gabarro, J. Mrukowicz, T. Vesikari, T. Verstraeten/ /Pediatr Infect Dis J. 2006;25:7-11.

3. Ротавірусна інфекція: особливості лабораторної діагностики, клінічного перебігу та профілактики у новонароджених / І. В. Дзюблик, Є. Є. Шунько, О. О. Костенко [та ін.] // Український медичний часопис. - 2007. - .№3/59 (V-VI). C. 102-107.

4. Дзюблик I. В. Внутрішньолікарняна ротавірусна інфекція у відділеннях інтенсивної терапії та патології новонароджених: вірусологічний моніторинг та профілактика / І. В. Дзюблик, О. О. Костенко, О. В. Ковалюк // Збірник наук. праць НМАПО імені П. Л. Шупика. - 2006. - Вип. 15, кн. 1. - C. 655-660.

5. Rotavirus vaccines: current prospects and future challenges/ Glass R., Parashar U., Bresee J. [et al.] // Lancet. - 2006 July. 22;368. - P. 323-32.

6. Наказ МОЗ України від 09.09.2010 №765 "Про порядок так і особливо серед немовлят: суттєво зменшиться кількість госпіталізацій, амбулаторних відвідувань, інфекцій з тяжким перебігом хвороби тощо. Результати досліджень можуть бути використані експертами та спеціалістами установ охорони здоров'я при вирішенні задач, направлених на попередження спалахів та епідемій, а також при прогнозуванні достатніх обсягів засобів специфічної профілактики РВІ в Україні.

проведення профілактичних щеплень в Україні та контроль якості й обігу медичних імунобіологічних препаратів".

7. Safety and efficacy of an attenuated vaccine against severe rotavirus gastroenteritis/G. M. Ruiz-Palacios, I. Perez-Schael, F. R. Velazquez, [et al.] //N . Engl. J. Med. - 2006. Vol. - 354(1). - P. 11-22.

8. Evaluation of safety, immunogenicity and efficacy of an attenuated rotavirus vaccine, RIX4414: A randomized, placebocontrolled trial in Latin American infants /B. Salinas, I. Perez Schael, A. C. Linhares, G. M. Ruiz Palacios, [et al] //Pediatr. Infect. Dis. J. - 2005.Vol. - 24(9). - P. 807-16; 17.

9. Efficacy of RIX4414 live attenuated human rotavirus vaccine in Finnish infants/ T. Vesikari, A. Karvonen, L. Puustinen [et al.] // Pediatr. Infect. Dis. J. - 2004. - Vol. 23(10). - P. 937-943.

10. Public health impact and cost effectiveness of mass vaccination with live attenuated human rotavirus vaccine (RIX4414) in India: model based analysis/ J. Rose, R. L. Hawthorn, B. Watts, M. E. Singer// BMJ. - 2009. Vol. 25. - P. 339-3653.

11. Prevention of rotavirus gastroenteritis among infants and children: recommendations of the advisory committee on 
immunization practices (ACIP)/ M. M. Cortese, Parashar // UD.MMWR Recomm. Rep. - 2009. - Vol. 58. - P. 1-25.

12. Beck J. R. The Markov process in medical prognosis / J. R. Beck, S. G. Pauker// Med. Decis Making. - Vol. 3. - 1983. - P. 419-458.

13. Sonnenberg F. A. Markov models in medical decision making: A practical guide / F. A. Sonnenberg, J. R. Beck // Med. Decis. Making - Vol. 13. 1993. - P. 322-338.

14. PubMed http://www.ncbi.nlm.nih.gov/pubmed/

15. Global illness and deaths caused by rotavirus disease in children/U. D. Parashar, E. G. Hummelman, J. S. Bresee [et al.] // Emerg. Infect. Dis. 2003. - Vol. 9. - P. 565-572.

16. Rotavirus infections in infants as protection against subsequent infections/ F. R. Velazquez, D. O. Matson, J. J. Calva [et al.] // N. Engl. J. Med. - 1996. - Vol. 335. - P. 1022-1028.

17. Angel J. Rotavirus vaccines: recent developments and future considerations / Angel J., Franco M. A., Greenberg H. B. // Nat. Rev. Microbiol. - 2007. - Vol. 5. - P. 529-539.

18. WHO. World Health Statistics 2011. Geneva, WHO, 2011 http://www.who.int/whosis/whostat/2011/en/

19. Burden of rotavirus gastroenteritis in the pediatric population in Central and Eastern Europe: serotype distribution and burden of illness/ I. Ogilvie, H. Khoury, A. C. El Khoury, M. M. Goetghebeur // Hum. Vaccin. - 2011. - Vol. 7(5). P. 523-533.

20. Гострі кишкові інфекції у дітей : навч.-метод. посіб. для лікарів-інтернів / [за ред проф. С. О. Крамарева]. - К. : Червона Рута-Турс, 2007. - 132 с.

21. Ротавіруси групи А та аденовіруси у новонароджених
3 перинатальною патологією: клініко-вірусологічне спостереження / Є. Є. Шунько, І. В. Дзюблик, Л. В. Омельченко, С. О. Соловйов // Соврем. педиатрия. - 2011. - № 2. - С. 89-95.

22. Early protection against severe rotavirus gastroenteritisRIX4414 experience in Latin America / P. Lopez, A. Linhares, I. Perez-Schael [et al.] // In: 24th Annual Meeting of the European Society of Infectious Diseases; 2006 May 3-5. Basel, Switzerland: 2006.

23. Efficacy and safety of an oral live attenuated human rotavirus vaccine against rotavirus gastroenteritis during the first 2 years of life in Latin American infants: a randomised, double-blind, placebo-controlled phase III study / A. C. Linhares, F. R. Velazquez, I. Perez-Schael [et al.] // Lancet. - 2008. - Vol. 371. - P. 1181-1189.

24. Molecular typing of rotaviruses, isolated on the territory of Ukraine / S. Soloviov, O. Trokhimenko, I. Dzyublyk // Clinical microbiology and infection. Special Issue: Abstracts of the 21 st ECCMID/27th ICC, Milan, Italy, 7-10 May 2011, Volume 17, Issue Supplements 4, S735.

25. Соловйов С. О. Математичне моделювання як сучасний інструмент прогнозування ефективності протиротавірусних вакцин / С. О. Соловйов // Медична інформатика та інженерія. - 2011.- № 2. - С. 59-63.

26. Дзюблик І. В. Нові підходи до прогнозування генотипспецифічної ефективності вакцини РОТАРІКС для профілактики ротавірусної інфекції в Україні / Дзюблик I. В., Соловйов С. О. // Педіатрія, акушерство та гінекологія. 2011. - T.73, № 3. - С. 80-83. 